\title{
Peningkatan Disiplin Belajar Melalui Pola Asuh Orangtua Kristen Berdasarkan Amsal 22:6 Siswa Kelas VII SMP Negeri 3 Tarutung Kabupaten Tapanuli Utara Tahun Pembelajaran 2018/2019
}

\author{
Ronny Simatupang \\ Prodi Pendidikan Agama Kristen, Institut Agama Kristen Negeri Tarutung
}

\begin{abstract}
Abstrak
Penelitian ini bertujuan untuk mengetahui pengaruh pola asuh orang tua kristen berdasarkan Amsal 22:6 terhadap disiplin belajar siswa Kelas VII SMP Negeri 3 Tarutung Kabupaten Tapanuli Utara Tahun Pembelajaran 2018/2019. Populasi dalam penelitian ini adalah seluruh siswa-siswi beragama kristen berjumlah 195 orang. Sampel diambil secara acak sebesar $20 \%$ dari jumlah populasi yaitu sebanyak 40 orang. Ujicoba dilakukan kepada 30 orang siswa. Dari persamaan regeresi diperoleh a) $\hat{Y}=13,10+0,73 \mathrm{X}, \mathrm{F}_{\text {hitung }}>\mathrm{F}_{\text {tabel }}$ yaitu $136,47>4,08$ menunjukkan bahwa persamaan regresi pola asuh orang tua kristen berdasarkan Amsal 22:6 terhadap disiplin belajar siswa adalah linier atau berbanding lurus, artinya semakin besar pengaruh pola asuh orang tua kristen berdasarkan Amsal 22:6 maka semakin baik disiplin belajar siswa. Besarnya persentase pengaruh pola asuh orang tua kristen berdasarkan Amsal 22:6 terhadap disiplin belajar siswa sebesar $=78,22 \%$. Dari uji hipotesa di peroleh nilai $t_{\text {hitung }}>t_{\text {tabel }}$ yaitu 6,226 $>2,021$ sehingga diketahui bahwa hipotesa penelitian diterima yaitu terdapat pengaruh yang positif dan signifikan antara pola asuh orang tua kristen berdasarkan Amsal 22:6 terhadap disiplin belajar siswa.
\end{abstract}

Katakunci : disiplin belajar siswa, pola asuh orang tua kristen berdasarkan amsal 22:6

\begin{abstract}
This study aims to determine the effect of parenting of Christian parents based on Proverbs 22: 6 on the learning discipline of Class VII students of SMP Negeri 3 Tarutung, North Tapanuli Regency, 2018/2019 Academic Year. The population in this study were all Christian students, amounting to 195 people. Samples were taken randomly by $20 \%$ of the total population of 40 people. Trials were conducted on 30 students. From the regression equation obtained a) $\hat{Y}=13.10+0.73 X, F_{\text {count }}>F_{\text {table }}$ is 136.47> 4.08 shows that the regression equation for Christian parenting based on Proverbs 22: 6 to student learning discipline is linear or directly proportional This means that the greater the influence of parenting Christians based on Proverbs 22: 6, the better the discipline of student learning. The large percentage of the influence of parenting Christians based on Proverbs 22: 6 on student learning discipline is = $78.22 \%$. From the hypothesis test, the value of $t_{\text {count }}>t_{\text {table }}$ is $6.226>2.021$ so it is known that the research hypothesis is accepted, that there is a positive and significant influence between parenting patterns of Christian parents based on Proverbs 22: 6 on student learning discipline.
\end{abstract}

Keywords: student learning discipline, parenting Christian parents based on proverbs 22:6

53 Korespondensi mengenai artikel dapat dilakukan kepada: Ronny Simatupang, Institut Agama Kristen Negeri Tarutung, Jl. Raya Tarutung-Siborong KM 11, Silangkitang, Sipoholon, Tapanuli Utara (22452), Indonesia e-mail Corresponding: ronnysimatupang1975@gmail.com 


\section{PENDAHULUAN}

Suatu bangsa memerlukan sumber daya manusia yang berkualitas untuk melanjutkan pembangunan disegala bidang. Bidang pendidikan salah satu sarana dan prasarana bangsa untuk memajukan dan meningkatkan kualitas sumber daya manusia, sehingga pendidikan merupakan faktor yang penting yang harus diperhatikan dalam rangka mewujudkan pembangunan suatu bangsa. Oleh karena itu pemerintah memberikan perhatian yang serius terhadap pendidikan. Dalam hal ini keluarga merupakan lingkungan pendidikan pertama dan utama bagi anak yang mempunyai peranaan sangat penting dalam upaya mengembangkan kepribadiaan anak. Sejak semula Allah telah memberikan mandat kepada para orang tua supaya mendidik, mengajar, dan menuntun anakanak agar mengenal pribadi Allah serta firmanNya. Dalam kehidupan keluarga orang tua mengharapkan anaknya berhasil. Kesuksesan seorang anak merupakan idaman setiap orang tua. Oleh karena itu orang tua berupaya untuk membentuk anak sesuai dengan keinginan mereka sebagai anak yang sukses. Seperti yang tertulis dalam (Amsal 22:6) mengatakan "Didiklah orang muda menurut jalan yang patut baginya, maka pada masa tuanya pun ia tidak akan menyimpang dari pada jalan itu". Pendampingan orang tua sangat diperlukan juga dalam mengeksplorasi potensi dalam diri mereka, anak-anak akan terus berkembang dalam hal fisik, intelektual, dan kejiwaan baik itu melalui perawatan dan perlakuaan yang baik dari orang tua. Apabila seorang anak telah merasa aman dan mampu memenuhi kebutuhan secara baik, maka ia akan memiliki kehidupan yang teratur. Disiplin belajar sering dikaitkan dengan ketundukan pada peraturan atau kebiasaan yang telah disepakati untuk dilaksanakan. Perbuatan disiplin membutuhkan upaya tertentu seperti rutinitas, tepat waktu, serta melaksanakan perintah dengan baik dan taat. Sebaliknya pelanggaran terhadap disiplin dapat berupa terlambat, melalaikan tugas dan membolos. Disiplin belajar tidak tumbuh dengan sendirinya melainkan adanya bantuan dari pendidik, baik dari orang tua, guru maupun masyarakat. Orang tua berpengaruh penting dalam pembentukan disiplin belajar di rumah yaitu dengan memberikan teladan dan pola asuh yang baik bagi anak dan mencukupi kebutuhan anak. Guru berpengaruh dalam kedisiplinan belajar di sekolah seperti masuk sekolah sebelum bel berbunyi, tidak membolos sebelum jam pelajaran sekolah berakhir. Selain orang tua dan sekolah kedisiplinan belajar dapat tumbuh dengan adanya bantuan dari masyarakat. Apabila kondisi masyarakat memiliki tingkat kedisiplinan belajar yang tinggi, maka dengan sendirinya akan berpengaruh pada anak tersebut, demikian pula dengan sebaliknya. Berdasarkan pengamatan penulis ketika observasi awal yaitu di SMP Negeri 3 Tarutung Kabupaten Tapanuli Utara masih terdapat sekelompok siswa yang tingkat kedisiplinan belajarnya masih rendah. Ada beberapa siswa dalam mengikuti pelajaran di kelas terkesan tidak atau kurang serius bahkan kadang terkesan semaunya. Siswa datang terlambat, siswa sering tidak mencatat, siswa tidak segera memasuki kelas meskipun bel tanda masuk telah berbunyi, siswa tidak mengerjakan tugas, siswa lebih senang 
berbicara dengan teman-temannya dari pada mencoba mengerjakan soal, tidak mendengarkan dengan serius saat guru sedang menerangkan, siswa sudah lebih banyak waktunya untuk pergi ke warnet, anak lebih mengutamakan bermain dengan teman-temannya setelah pulang sekolah, siswa tidak lagi menghiraukan peraturan yang diterapkan oleh orang tua dalam keluarganya dan tidak mengerjakan tugas dengan maksimal. Penulis melanjutkan pertanyaan kepada siswa mengenai orang tua. Beberapa siswa kelas VII diberi pertanyaan mengenai sikap orang tua terhadap kegiatan belajar siswa di rumah. Terdapat siswa yang menjawab bahwa orang tua mengatur kegiatan belajar di rumah dan memarahi anak jika tidak belajar. Siswa jarang diperbolehkan untuk bermain bersama teman. Menurut Boehlke (2007: 15) "Orang tua Kristen adalah orang yang bertanggung jawab mengasuh, mendidik, memotivasi dan mengawasi pendidikan anaknya pada sekolah yang setaraf dengan sekolah dasar ini”. Selanjutnya menurut Chrysostomus dalam Boehlke (2007: 118) "Sebagai seorang anak dibimbing menjadi olahragawan bagi Kristus dengan menanamkan disiplin. Demikian pula halnya orang tua, mereka hendaknya menganggap dirinya bagaikan seorang pelukis atau pemahat. "Seniman itu bekerja setiap hari, cat ini untuk dipoleskan pada kanvas, kalau pelukis itu kurang senang dengan sesuatu polesan, maka ia menghilangkan bagian yang tertentu itu dan ia mulai mencatatnya kembali sampai ia merasa agak puas dengan hasilnya. Demikian seharusnya orang tua. tetapi "lukisan" atau "patung" yang dibuatnya itu jauh lebih bermakna karena pemiliknya ialah Tuhan. Kitab Amsal adalah buku hikmat yang sangat berlaku digunakan pada masa pengembangan ilmu pengetahuan dan teknologi Israel, yaitu pada masa pembangunan umat. Salomo membangun bait suci dan membangun masyarakat. Salah satu kebijaksanaannya yang perlu diperhatikan adalah pengumpulan gagasan-gagasan filsafat, pengalaman, pengajaran hikmat berdasarkan pada "takut akan Tuhan", unsur-unsur pendidikan dan kebaktian serta pengetahuan alam (Amsal 1:7; Mazmur 111:10; Ayub 28:28). Lasor (2000: 89), menuliskan bahwa kitab Amsal merupakan kumpulan tulisan dengan aneka ragam gaya yang berbeda-beda. Keanekaragaman ini menunjukkan ruang lingkup yang luas dari masyal Ibrani yang biasa diterjemahkan "Amsal" dalam bahasa Indonesia. Kata masyal mungkin diambil dari akar kata yang berarti "menyerupai" atau "dibandingkan dengan". Beberapa ahli menghubungkan masyal dengan akar kata yang berarti memerintah sehingga Amsal berarti ucapan pemimpin yang mengandung kuasa dan makna khusus. Amsal pada mulanya mungkin merupakan semacam perbandingan, seperti yang sering terdapat dalam perjanjian lama yakni "perkataan yang menyenangkan adalah seperti sarang madu, manis bagi hati dan obat bagi tulang-tulang" (Amsal 16:24). Menurut Kidner (1964: 13) mengatakan bahwa: "Kitab Amsal merupakan kunci untuk menuju realis kehidupan dan kitab Amsal juga merupakan kalkulasi dari setiap langkah kehidupan manusia yang berpusat dan berpedoman kepada kehendak Allah". Ruang cakupannya dalam kehidupan sehari-hari seperti politik, pemerintahan, 
JURNAL CHRISTIAN HUMANIORA

Vol.4, No.1, May 2020, pp. 53-62

p-ISSN: 2598-6317- e-ISSN: 2599-196

ekonomi, pertanian dan juga perilaku, percakapan, hakekat persekutuan yang cenderung kepada manusiawi dan universal.

Tafsiran Amsal 22:6: Didiklah orang muda menurut jalan yang patut baginya, maka pada masa tuanya pun ia tidak akan menyimpang dari pada jalan itu. Kata kunci: 1). Didiklah. Dalam bahasa Ibrani didiklah disebut חָּנָ (hânak) merupakan kata kerja imperative maskulin tunggal yang artinya mengabdikan, melatih dan dalam bahasa Inggris disebut "Train up". Selanjutnya kata didik dalam KBBI (2008: 263) berasal dari kata didik yang artinya memelihara dan memberi latihan (ajaran, tuntunan, pimpinan) mengenai akhlak dan kecerdasan pikiran. Jadi didiklah adalah mengabdikan, memelihara, melatih, memberi ajaran, tuntunan dan pimpinan dalam kecerdasan pikiran. Kata Ibrani untuk חָּנְּ (hânak) berarti untuk mendedikasikan, mengabdikan. Hal ini digunakan mendedikasikan rumah (Ul 20: 5), kuil (1 Raja-raja 8:63; 2 Taw 7:5), dan gambar (Dan 3:2). Kata

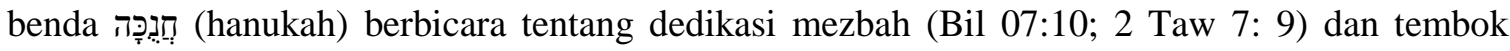
Yerusalem. Hanya di Amsal 22:6 adalah kata kerja yang diterjemahkan "melatih." Kata ini (hânak) tampaknya termasuk ide mempersempit, membatasi, atau memagari (Twot Lexicon). Selanjutnya kata mengabdikan dalam KBBI (2008: 2) berarti menjadikan diri abdi; memperhambakan diri. Gleason L. Archer (1982: 252) " Dia menyarankan bahwa dalam ayat 6 ini memberikan berbagai arti: "Mengabdikan anak kepada Allah,"Siapkan anak untuk tanggung jawab masa depannya, latihan atau melatih anak untuk dewasa". Dari arti ini dapat kita pahami bahwa orang tua memang benar-benar harus bisa menjadikan diri abdi atau berkorban agar bisa mendidik anak-anak mereka tidak terpengaruh dari yang jahat dan pelatihan anak melibatkan mempersempit perilaku anak dari kejahatan dan menuju kesalehan dan mengarahkannya ke jalan yang benar sehingga anak-anak mereka dapat bertanggung jawab untuk masa depannya. 2). Jalan. Kata jalan disini menggunakan kata (Derek) kata ini ialah kata benda 2 jamak construct. Kata "derek" ini terutama digunakan di batang Qal, meskipun beberapa contoh dalam Hiphil juga terjadi. Biasanya muncul dalam bahan puitis, sering dalam kitab nabi-nabi dan Mazmur. Tuhan sering sebagai subjek dari kata kerja ini, terutama bila digunakan dalam arti kiasan (Twot Lexicon, Bible work 9). "derek" kata ini terdapat dua kali dalam Ayub dan sekali dalam Amsal yang mengacu pada pekerjaan Tuhan dalam konteks penciptaan. "derek"; Way, jalan, perjalanan, cara, kerja, terkait dengan kata kerja “darak" "untuk menginjak, menginjak-injak", oleh karena itu yang pertama merujuk, untuk jalan yang dikenakan dengan berjalan konstan. "Menurut jalan yang patut baginya," secara harafiah itu artinya "menurut jalannya" (al-pi-darko); 'al-pi ("menurut perkataan dari”) biasanya berarti "mengikuti ketentuan atau peraturan," "tunduk pada," "sesuai dengan." Sedang darko berasal dari kata "derek ("jalan”), dan ini bisa berarti "adat-istiadat dari, sifat dari, cara bertindak, pola perilaku dari” seseorang. Selanjutnya (WTM Morphology + TWOT Hebrew Wordbook Entry) mengatakan: Ketika kata kerja terjadi di batang Hiphil, secara konsisten mengacu kepada Tuhan saat dia memimpin orang benar di jalan yang lurus. Atau, lebih umum, jalan metafora kejujuran atau 
kebenaran (Amsal 4:11; Mazmur 25: 5, 9). Sejajalan dengan hal diatas (C. F. Keil, F. Delitzsch, Commentary On The Old Testament 10 Volumes, PC Study 5, elektronik) Jalan berarti dalam Amsal tidak berarti kepribadian atau tahap dalam hidup, adalah lebih baik untuk mengatakan bahwa "jalan" berarti jalan yang tepat, jalan yang bijaksana, hidup saleh, yang sering ditekankan dalam Amsal dan pada dasarnya jalan hikmat. Berdasarkan hasil tafsiran teks Amsal 22:6, maka yang menjadi indikator dalam penelitian ini adalah: 1). Menuntun sesuai dengan jalan yang tepat. 2). Menuntun sesuai dengan jalan yang bijaksana. 3). Melatih anak dengan pola kesalehan. a). Berbicara sopan. b). Tepat waktu. c). Menegur anak ketika berbuat salah. d). Memberi hukuman dan hadiah sesuai dengan perbuatan anak.

Disiplin mengalir dari kasih, kasih menginginkan yang terbaik untuk seseorang. Lessin (2002: 77) Disiplin adalah bagian dari kasih, menolak untuk mendisiplinkan anak-anak adalah suatu tanda yang jelas bahwa tidak mempunyai kasih yang Allah inginkan kita miliki terhadap anak-anak. Kata disiplin berasal dari kata "Discipline" dan "disciple dan melatih" artinya memberi pengajaran, mendidik untuk murid”. Disiplin adalah suatu keadaan tertib di mana orang-orang yang bergabung dalam suatu sistem tunduk pada peraturan yang ada dengan senang hati. Disiplin meliputi pembentukan sifat anak secara menyeluruh melalui pemberian semangat pada tingkah laku yang baik. Kata disiplin merupakan istilah yang sering kita dengarkan. Menurut Sidjabat (2009: 317) Disiplin mengandung dua segi, pertama sebagai benda, disiplin berarti seperangkat aturan atau tata tertib yang diterapkan dalam kegiatan belajar mengajar guna membantu siswa mengembangkan pola tingkah laku yang sehat. Yang kedua sebagai kata kerja, disiplin artinya upaya untuk membimbing orang lain agar mengembangkan sikap dan pola hidup (perkataan, pemikiran, perbuatan) yang bermanfaat bagi keberhasilan tugas belajar. Belajar seperti yang diungkapkan Dalyono (2005: 49) "Belajar adalah suatu usaha atau kegiatan yang bertujuan mengadakan perubahan di dalam diri seseorang mencakup perubahan tingkah laku, sikap, kebiasaan, ilmu pengetahuan, keterampilan dan sebagainya”. Hurlock yang dikutip Gunarsa (2010: 81) mengatakan bahwa disiplin belajar adalah "sebagai proses dari latihan atau belajar bersangkut paut dengan pertumbuhan dan perkembangnnya". Pentingnya disiplin orang tua bagi anaknya bukan saja karena alasan sosiologis dan psikologis tetapi juga teologis. Alkitab, Firman Tuhan berbicara banyak mengenai pentingnya disiplin dalam kehidupan keluarga. Disiplin bersifat mendidik dan memelihara, mendisiplinkan anak berarti melindungi anak dari bahaya. Evans (2011: 103) mengatakan "Disiplin tidak berarti sebagai suatu hukuman untuk Stindakan-tindakan yang salah, tetapi suatu koreksi dari sikap-sikap yang salah yang akan mengarah pada tindakan yang salah". Dalam hal ini disiplin dapat dikatakan sebagai proses latihan atau pendidikan dari pada berupa hukuman. Marbun (2010: 60) mengatakan disiplin merupakan faktor penunjang yang sangat penting menjadikan seseorang mencapai hidup yang lebih baik. Amsal 6:6-11 " Hai pemalas 
JURNAL CHRISTIAN HUMANIORA

Vol.4, No.1, May 2020, pp. 53-62

p-ISSN: 2598-6317- e-ISSN: 2599-196

pergilah kepada semut, perhatikanlah lakunya dan jadilah bijak. Biarpun tidak ada pemimpinnya, pengaturnya, penguasaanya, ia menyediakan rotinya pada musim panas, dan mengumpulkan makanannya pada waktu panen”. Kitab Amsal ini mengajak kita untuk disiplin. Salah satu disiplin yang dimaksud adalah pengguanaan waktu yang kita miliki, unsur disiplin dari ayat ini adalah menggunakan waktu dengan sebaik-baiknya, dan bekerja dengan kontiunitas. Orang-orang yang memiliki disiplin tinggi adalah mereka yang menggunakan setiap kesempatan untuk sesuatu yang bermakna. Dalam pelaksanaan suatu program dan kegiatan harus memiliki manfaat dan tujuan merupakan usaha yang dilakukan oleh orang tua dalam mengendalikan perilaku yang telah melebihi dan merugikan dia atau pun teman dekatnya. Fungsi utama disiplin adalah "Untuk belajar mengendalikan diri dengan mudah menghormati dan mematuhi otoritas". Sehubungan dengan itu Lessin (2002: 81), mengatakan bahwa tujuan utama dari disiplin untuk anak-anak adalah supaya mereka menjadi pribadi yang mengenal dan menyerahkan diri kepada Tuhan supaya kehidupan mereka mencerminkan sifat Kristus". Disiplin bermanfaat bagi siswa untuk memperoleh perubahan ke arah yang lebih baik bagi lingkunganya, sesuai dengan aturan yang ada dalam menciptakan situasi yang tepat bagi siswa untuk mengembangkan bakat yang dimilikinya. Gunarsa (2012: 135) mengemukakan bahwa "Fungsi utama disiplin adalah untuk belajar mengendalikan diri dengan mudah menghormati serta mematuhi otoritas". Menurut Chalke (2009: 38) "disiplin mempunyai banyak unsur selain hukuman yaitu pujian, dorongan, ucapan terima kasih, mendengarkan dan menghargai hal-hal tersebut mendasari pembentukan rasa percaya diri dan disiplin pribadi anak". Selanjutnya indikator disiplin belajar menurut Sofchah (2001: 3) mengatakan agar seorang siswa dapat belajar dengan baik ia harus bersikap disiplin, terutama disiplin dalam hal-hal sebagai berikut: 1). Disiplin dalam menepati jadwal belajar. 2). Disiplin dalam mengatasi semua godaan yang akan menunda-nunda waktu belajar. 3). Disiplin terhadap diri sendiri untuk dapat menumbuhkan kemauan dan semangat belajar baik di sekolah seperti menaati tata tertib, maupun disiplin di rumah seperti teratur dalam belajar. 4). Disiplin dalam menjaga kondisi fisik agar selalu sehat dan fit dengan cara makan yang teratur dan bergizi serta berolahraga secara teratur.

\section{METODE PENELITIAN}

Metode penelitian yang digunakan adalah metode penelitian kuantitatif. Dalam penelitian ini penulis menentukan lokasi penelitian pada siswa kelas VII SMP Negeri 3 Tarutung Kabupaten Tapanuli Utara. Menurut Sugiyono (2009: 117) mengatakan bahwa "Populasi adalah wilayah generalisasi yang terdiri atas obyek/subyek yang mempunyai kualitas dan karakteristik tertentu yang ditetapkan oleh peneliti untuk dipelajari dan kemudian ditarik kesimpulannya". Adapun yang menjadi populasi dalam penelitian ini 
adalah sebanyak 195 orang. Sampel adalah bagian dari jumlah dan karakteristik yang dimiliki oleh populasi tersebut. Arikunto (2003: 120) “apabila subjeknya kurang dari 100 orang, lebih baik diambil semua sehingga penelitiannya merupakan penelitian populasi. Jika jumlah subjeknya lebih besar, dapat diambil antara 10\%-15\% atau 20\%-25\% atau lebih". Sampel dalam penelitian ini dengan mengambil 20\% dari keseluruhan jumlah siswa kelas VII yaitu sebanyak 40 orang. Untuk memperoleh instrumen yang tepat berdasarkan kisi-kisi angket yang telah disusun tersebut, maka terlebih dahulu angket yang telah disusun diujicobakan kepada 30 responden di kelas VII SMP Negeri 3 Tarutung Kabupaten Tapanuli Utara. Sebelum uji reliabilitas dilakukan, perlu dicari terlebih dahulu varians setiap butir itemnya dengan menggunakan rumus sebagai berikut:

$$
\sigma b^{2}=\frac{\sum x^{2}-\frac{\left(\sum X^{2}\right)}{N}}{N}
$$

Untuk mencari reliabilitas instrumen digunakan dengan rumus alpha sebagaimana dikatakan oleh Arikunto (2010: 239):

$$
r 11=\left\{\frac{k}{k-1}\right\}\left\{\frac{1-\sum \sigma b^{2}}{\sum \sigma t^{2}}\right\}
$$

Untuk menguji data yang signifikan (taraf nyata) digunakan rumus (t) yang dikemukakan oleh Arikunto (2003: 263) dan mengkonsultasikan dengan (t) tabel yaitu:

$$
t=r \sqrt{\frac{n-2}{1-r^{2}}}
$$

Untuk mengetahui derajat pengaruh variabel X (Disiplin belajar) terhadap variabel Y (pola asuh orangtua Kristen berdasarkan Amsal 22:6), dilakukan perhitungan persamaan regresi sederhana Sudjana (2002: 315) yaitu:

$$
\hat{y}=\ddot{a}+b x
$$




\section{HASIL DAN PEMBAHASAN}

Berdasarkan hasil penelitian yang dilakukan kepada siswa kelas VII SMP Negeri 3 Tarutung Tahun Pembelajaran 2018/2019 yang menunjukkan bahwa terdapat peningkatan antara Disiplin Belajar melalui Pola Asuh Orang Tua Kristen berdasarkan Amsal 22:6. Hal ini berarti jika Pola Asuh Orang Tua Kristen berdasarkan Amsal 22:6 dilaksanakan dengan baik, maka akan meningkatkan Disiplin Belajar siswa. Adapun pembahasan hasil penelitian sebagai berikut: 1). Dari hasil penelitian diketahui item yang memperoleh nilai tertinggi untuk variabel $\mathrm{X}$ adalah item nomor 28 dengan skor 150 dan nilai rata-rata 3,75 yaitu ketika ulangan, siswa mengerjakan ulangan tanpa menyontek. Dan item yang memperoleh nilai terendah dari item yang lain adalah item nomor 20 dengan skor 95 dan nilai nilai rata-rata 2,38 yaitu siswa mengerjakan pertanyaan-pertanyaan yang ada di dalam paket tanpa diperintah guru. 2) Dari hasil penelitian diketahui bahwa item yang memperoleh nilai tertinggi untuk variabel Y tentang Pola Asuh Orang Tua berdasarkan Amsal 22:6 adalah item nomor 3 dengan skor 155 dan nilai rata-rata 3,88 yaitu orang tua mengingatkan siswa untuk pergi beribadah. Dan item yang memperoleh nilai terendah yaitu nomor 5 dengan skor 116 dan nilai rata-rata 2,9 yaitu Orang Tua kurang mendengarkan pendapat anak. 3) Berdasarkan uji hubungan diperoleh $r_{\text {hitung }}>r_{\text {tabel }}$ yaitu 0,47 > 3,67 artinya terdapat hubungan yang positif antara Pola Asuh Orang Tua Kristen berdasarkan Amsal 22:6 dengan Disipin Belajar Siswa Kelas VII SMP Negeri 3 Tarutung Tahun Pembelajaran 2018/2019. 4) Setelah dilakukan uji determinasi diperoleh peningkatan Disiplin Belajar Siswa melalui Pola Asuh Orang Tua Kristen berdasarkan Amsal 22:6 Siswa Kelas VII SMP Negeri 3 Tarutung Tahun Pembelajaran 2018/2019 sebesar $\left(\mathrm{r}^{2}\right)=78,22 \%$ sementara 21,78\% dipengaruhi oleh faktor lain. 5) Dari uji regresi diperoleh: a) Persamaan regresi adalah $\hat{\mathrm{Y}}=13,10+0,73 \mathrm{X}$ artinya dalam keadaan konstanta = 13,10, maka Disiplin Belajar Siswa Kelas VII SMP Negeri 3 Tarutung akan meningkat 0,73 kali dari satuan nilai Pola Asuh Orang Tua Kristen berdasarkan Amsal 22:6. 6) Dari uji hipotesa diperoleh nilai $t_{\text {hitung }}>\mathrm{t}_{\text {tabel }}$ yaitu $6,226>2,021$ maka hipotesa penelitian diterima yaitu terdapat peningkatan yang positif dan signifikan antara Disiplin Belajar melalui Pola Asuh Orang Tua Kristen berdasarkan Amsal 22:6 Siswa Kelas VII SMP Negeri 3 Tarutung Tahun Pembelajaran 2018/2019. 


\section{KESIMPULAN}

Berdasarkan uji hubungan diperoleh $r_{\text {hitung }}>r_{\text {tabel }}$ yaitu 0,47 $>3,67$ artinya terdapat hubungan yang positif antara Disiplin belajar melalui Pola Asuh Orang Tua Kristen berdasarkan Amsal 22:6 Siswa Kelas VII SMP Negeri 3 Tarutung Tahun Pembelajaran 2018/2019. Setelah dilakukan uji determinasi diperoleh peningkatan Disiplin belajar melalui Pola Asuh Orang Tua Kristen berdasarkan Amsal 22:6 Siswa Kelas VII SMP Negeri 3 Tarutung Tahun Pembelajaran 2018/2019 sebesar $\left(\mathrm{r}^{2}\right)=$ $78,22 \%$ sementara $21,78 \%$ dipengaruhi oleh faktor lain. Dari uji regresi diperoleh: a) Persamaan regresi adalah $\hat{Y}=13,10+0,73 X$ artinya dalam keadaan konstanta $=13,10$, maka Disiplin Belajar Siswa Kelas VII SMP Negeri 3 Tarutung akan meningkat 0,73 kali dari satuan nilai Pola Asuh Orang Tua Kristen berdasarkan Amsal 22:6. Dari uji hipotesa diperoleh nilai $t_{\text {hitung }}>t_{\text {tabel }}$ yaitu 6,226 > 2,021 maka hipotesa penelitian diterima yaitu terdapat peningkatan yang positif dan signifikan antara Disiplin belajar melalui Pola Asuh Orang Tua Kristen berdasarkan Amsal 22:6 Siswa Kelas VII SMP Negeri 3 Tarutung Tahun Pembelajaran 2018/2019.

\section{DAFTAR PUSTAKA}

Archer, Gleason L. 2004. Encyclopedia of Bible Difficulties. Malang: Gandum Mas. Arikunto, Suharsimi. 1996. Prosedur Penelitian. Jakarta: PT. Rineka Cipta.

2010. Prosedur Penelitian suatu pendekatan praktek. Yogyakarta: Rineka Cipta.

Arikunto, Suharsimi. 1996. Prosedur Penelitian. Jakarta: PT. Rineka Cipta. Cipta.

2010. Prosedur Penelitian suatu pendekatan praktek. Yogyakarta: Rineka

Boehlke, Robert R. 1991.Sejarah Perkembangan Pikiran Dan Praktek Pendidikan Agama Kristen. Jakarta : BPK Gunung Mulia.

Chalke, Steve. 2009. Kiat Menjadikan Anak Anda Sukses dan Bahagia. Yogyakarta: Andi.

C. F. Keil, F. Delitzsch, Commentary On The Old Testament 10 Volumes, PC Study 5, elektronik.

Dalyono, M. 2005. Psikologi Pendidikan. Jakarta: Rineka Cipta.

61 | Peningkatan Disiplin Belajar melalui Pola asuh Orangtua Kristen berdasarkan Amsal 22:6..., Ronny Simatupang Jurnal Christian Humanioran | http://e-journal.iakntarutung.ac.id/index.php/humaniora 
Delitzsch, D,D. 1950. Biblical Commentary on the Proverbs of Salomon. Michigan: Publishing Company Grand Rapids.

Evans, Jane. 2011. Help I'm a Mother. Jawa Timur: Gandum Mas.

Gunarsa, D, Singgih dan Ny. Gunarsa, Y, D, Singgih. 1986. Psikologi Perkembangan anak dan Remaja. Jakarta: BPK Gunung Mulia.

Hurlock, E.B. 1991. Psikologi Perkembangan Anak. Jakarta: Erlangga.

Kidner, Derek. 1964. The Proverbs An Introduction and Commentary. USA: University.

Lasor W, S. 2000. Pengantar perjanjian Lama II. Jakarta: BPK Gunung Mulia.

Lessin, Roy. 2002. Disiplin Keluarga. Jawa Timur: Gandum Mas.

Marbun, Purim. 2010. Building better life. Yogyakarta: ANDI.

Pusat Pendidikan Nasional. 2008. Kamus Umum Bahasa Indonesia. Jakarta: Balai Pustaka.

Sidjabat B.S. 2008. Membesarkan Anak Dengan Kreatif. Yogyakarta: ANDI

Sofchah, Sulistyowati. 2001. Disiplin belajar. Pustaka Setia Bandung. http://nuryanto69.blogspot.com/2020/2 /normal-o-false-false-false-en-us-X

Sudjana. 2002. Metode Statistika. Bandung: Tarsito.

Sugiyono. 2009. Metode Penelitian Pendidikan Pendekatan Kuantitatif, kualitatif dan $R \& D$. Bandung:Alfabet

Twot Lexicon, Bible work 9.

WTM Morphology + TWOT Hebrew Wordbook Entry.s 